\title{
VALIDITAS DAN RELIABILITAS INSTRUMEN KECEMASAN BELAJAR MATEMATIKA PADA SISWA MADRASAH ALIYAH SWASTA
}

\author{
Nurmawati \& Irma Suryani \\ IAIN Langsa \\ nurma16@ymail.com
}

\begin{abstract}
This article aimed on finding the validity and realibility of the instrument for the students' anxiety in learning mathematics. The method used in this research was quantitative research in survey type. The population and the sample of this research was 138 students MAS Raudhatun Najah Langsa. Techniques for collecting the data was non-test, in the type of questionnaires that has been analyzed by using Principal Components Analysis (PCA). After analyzed 31 items, 21 items showed the validity and realibilitty. The result showed that KMO-MSA values indicated that all instrument is valid and reliable. It can be used as an instrument for looking the students' anxiety in learning especially in learning math.

Keywords: Validity, Reliability, Students' Anxiety In Learning Mathematics.
\end{abstract}

\begin{abstract}
Abstrak
Penelitian ini bertujuan untuk mengetahui validitas dan reliabilitas instrumen kecemasan belajar matematika. Metode penelitian yang digunakan adalah metode survey yaitu dengan pendekatan kuantitatif. Populasi dalam penelitian ini adalah seluruh siswa MAS Raudhatun Najah Langsa yang berjumlah 138 siswa. Sampel dalam penelitian ini diambil dengan menggunakan teknik sampling jenuh dimana semua anggota populasi digunakan sebagai sampel. Teknik pengumpulan data yang digunakan adalah non tes yaitu dengan menggunakan instrumen angket. Sedangkan teknik analisis data yang digunakan dalam penelitian ini adalah analisis multivariat yaitu analisis faktor dengan metode Principal Components Analisis (PCA). Hasil penelitian melalui analisis faktor diperoleh nilai KMO-MSA sebesar 0,670, karena nilai KMO-MSA lebih dari 0,5 berarti data tersebut memenuhi syarat untuk analisis faktor. Selanjutnya dari 31 item pertanyaan yang dinilai layak untuk bisa mengikuti uji berikutnya sebanyak 21 item. Setelah dilakukan analis faktor, 21 item pertanyaan tersebut telah memenuhi syarat validitas dan reliabilitas untuk instrumen kecemasan belajar matematika.
\end{abstract}

Kata kunci: Validitas, Reliabilitas, Kecemasan belajar matematika 
172 | TAZKIR: Jurnal Penelitian Ilmu-ilmu Sosial dan Keislaman

Vol. 04 No. 1 Juni 2018

\section{PENDAHULUAN}

Belajar adalah suatu perubahan dalam diri seseorang yang terjadi karena pengalaman. Belajar merupakan kegiatan yang berproses dan merupakan unsur yang sangat fundamental dalam setiap penyelenggaraan jenis dan jenjang pendidikan. Ini berarti bahwa berhasil atau gagalnya pencapaian tujuan pendidikan sangat bergantung pada proses belajar. Sekolah merupakan lembaga pendidikan formal yang disediakan bagi peserta didik untuk melakukan proses belajar. Selama belajar di sekolah, para peserta didik diwajibkan untuk mengikuti semua mata pelajaran sesuai dengan kurikulum yang telah ditetapkan. Matematika merupakan salah satu mata pelajaran yang sangat penting untuk diajarkan kepada siswa karena matematika selalu digunakan dalam segala segi kehidupan.

Pembelajaran matematika adalah suatu proses atau kegiatan guru mata pelajaran matematika dalam mengajarkan matematika kepada siswanya yang di dalamnya terkandung upaya guru untuk menciptakan iklim dan pelayanan terhadap kemampuan, potensi, minat, bakat, dan kebutuhan siswa tentang matematika yang amat beragam agar terjadi interaksi optimal antara guru dengan siswa serta antara siswa dengan siswa dalam mempelajari matematika sehingga kegiatan belajar matematika menjadi lebih baik dan sesuai dengan tujuan pembelajaran matematika di sekolah. Tujuan pembelajaran matematika meliputi pemahaman konsep matematika, penggunaan penalaran pada pola dan sifat matematika, pemecahan masalah matematika, komunikasi matematika, dan penggunaan matematika dalam kehidupan sehari-hari.

Pada proses belajar mengajar, matematika merupakan salah satu mata pelajaran yang dianggap sulit dan sukar oleh sebagian besar siswa hal ini mungkin karena disebabkan oleh sifatnya yang abstrak, penuh angka, rumus dan memerlukan latihan. Terlebih dalam menyampaikannya guru monoton sehingga menimbulkan kesan membosankan atau bahkan penyampaian materi dari guru yang kurang dapat dipahami sehingga menambah ketidaksukaan terhadap matematika. Ketidaksukaan ini berdampak terhadap hasil belajar yang diperoleh siswa. ${ }^{1}$

Banyak faktor yang mempengaruhi hasil belajar, salah satunya adalah faktor internal yaitu faktor yang berasal dari dalam diri siswa yaitu kecemasan

${ }^{1}$ Aminah Ekawati, "Pengaruh Kecemasan terhadap Hasil Belajar Matematika Siswa Kelas VII SMPN 13 Banjarmasin", Jurnal Pendidikan Matematika, Vol 1, No.3 September-Desember 2015, hlm 164. 
yang dialami oleh siswa. Kecemasan merupakan suatu gejala normal yang terjadi. Kecemasan dianggap sebagai salah satu faktor penghambat dalam belajar yang dapat mengganggu kinerja fungsi kognitif seseorang dalam berkonsentrasi, mengingat, pembentukan konsep dan pemecahan masalah. Kecemasan matematika mengacu pada suasana hati yang tidak sehat seperti respon yang terjadi ketika beberapa siswa mengalami permasalahan matematika dan menampakkan dirinya dengan panik dan hilangnya pikiran, depresi dan tidak berdaya, gugup dan takut dan sebagainya. ${ }^{2}$

Kecemasan siswa berkaitan dengan perasaan cemas dan khawatir yang timbul dari dalam diri siswa. Perasaan ini dapat dikarenakan pemahaman terhadap konsep matematika yang lemah. Ini dapat dilihat dari hasil belajar siswa sebagian besar berada pada kualifikasi kurang. Menurut Hartanti dalam Aminah, perasaan cemas akan berdampak pada hasil belajar matematika karena dampak kecemasan membuat siswa melakukan perlawanan terhadap perasaan cemas, pada suatu kondisi kegiatan siswa akan terganggu yang menimbulkan siswa tidak berdaya untuk merubah kondisi dan menyebabkan siswa menjadi kurang percaya terhadap kemampuan yang dimilikinya. ${ }^{3}$

Kecemasan siswa dalam menghadapi pelajaran matematika dapat diartikan sebagai emosi siswa yang tidak menyenangkan, yang dicirikan sebagai kegelisahan, ketidakenakan, kekhawatiran, ketakutan yang tidak mendasar bahwa akan terjadi hal-hal yang tidak diinginkan ketika siswa menghadapi pelajaran matematika.

Kecemasan yang dialami siswa pada mata pelajaran matematika sering disebut sebagai kecemasan matematika (Mathematics Anxiety). Kecemasan terhadap matematika tidak bisa dipandang sebagai hal biasa, karena ketidakmampuan siswa dalam beradaptasi pada pelajaran menyebabkan siswa kesulitan serta fobi terhadap matematika yang akhirnya menyebabkan hasil belajar matematika rendah. Kecemasan dapat disebabkan karena ketidaksiapan siswa dalam mengikuti tes yang dilaksanakan. Ketidaksiapan ini salah satunya karena kurangnya pemahaman terhadap konsep matematika yang akan diujikan. ${ }^{4}$ Kecemasan siswa dalam pembelajaran matematika juga dapat

\footnotetext{
2 Aminah Ekawati, "Pengaruh Kecemasan... ,hlm 165.

3 Aminah Ekawati, "Pengaruh Kecemasan... ,hlm 168

4 Aminah Ekawati, "Pengaruh Kecemasan... ,hlm 165.
} 
disebabkan karena motivasi dan kepercayaan diri yang rendah pada diri siswa, hal ini dapat berpengaruh terhadap hasil belajarnya.

Kecemasan siswa terhadap matematika berpengaruh terhadap hasil belajarnya, hal ini sesuai dengan penelitian sebelumnya yang dilakukan oleh Laili Masruroh dan M. Dicky Reza dengan judul penelitian " Pengaruh kecemasan siswa pada matematika terhadap hasil belajar matematika di SMP". Subyek penelitiannya adalah siswa kelas VIII SMP PGRI 7 Sedati. Hasil penelitian menunjukkan ada hubungan antara kecemasan siswa pada matematika dan hasil belajar matematika sebesar 0,668 dan tergolong cukup tinggi. ${ }^{5}$ Penelitian lainnya dilakukan oleh Aminah Ekawati dengan judul penelitian "Pengaruh kecemasan terhadap hasil belajar matematika siswa kelas VII SMPN 13 Banjarmasin". Hasil penelitian menunjukkan ada pengaruh yang kuat antara kecemasan terhadap hasil belajar matematika siswa kelas VII SMPN 13 Banjarmasin. ${ }^{6}$

Mengingat pentingnya kemampuan matematika bagi siswa, maka pendidik harus mengetahui apakah siswa mengalami kecemasan belajar matematika atau tidak. Untuk mengetahui apakah siswa mengalami kecemasan belajar matematika, perlu disusun instrumen penelitian tentang kecemasan belajar matematika. Instrumen penelitian adalah suatu alat yang digunakan untuk mengukur fenomena alam maupun sosial yang diamati. Secara spesifik semua fenomena ini disebut variabel penelitian. ${ }^{7}$ Instrumen penelitian kecemasan belajar matematika yang disusun haruslah valid dan reliabel agar hasil penelitian yang diperoleh valid dan reliabel.

Validitas berasal dari kata validity, yang berarti sejauh mana ketepatan dan kecermatan suatu alat ukur dalam melakukan fungsi ukurnya. Suatu tes atau instrumen pengukuran dikatakan memiliki validitas yang tinggi apabila alat tersebut menjalankan fungsi ukurnya atau memberikan hasil ukur yang sesuai dengan maksud dilakukannya pengukuran teersebut. Artinya hasil ukur dari pengukuran tersebut tepat fakta atau keadaan sesungguhnya dari apa yang diukur. ${ }^{8}$ Sedangkan reliabilitas adalah suatu ukuran untuk mengetahui sejauh

${ }^{5}$ Laili Masruroh dan M. Dicky Reza, "Pengaruh Kecemasan Siswa pada Matematika terhadap Hasil Belajar Matematika di SMP", Jurnal Pendidikan Matematika, Vol 3, No.2 September 2015, hlm 177.

${ }^{6}$ Aminah Ekawati, "Pengaruh Kecemasan terhadap... hlm 164.

7 Sugiyono, METODE PENELITIAN PENDIDIKAN (Pendekatan kuantitatif, kualitatif dan RED), (Bandung: Alfabeta, 2009), hlm 148.

${ }^{8}$ H. Djaali dan Pudji Muljono, Pengukuran dalam bidang Pendidikan, (Jakarta: PT Gramedia Widiasarana, 2008), hlm 49. 
mana hasil pengukuran tetap konsisten bila diukur beberapa kali dengan alat ukur yang sama.

Instrumen yang valid dan reliabel merupakan syarat mutlak untuk mendapatkan hasil penelitian yang valid dan reliabel. Namun, hal ini masih dipengaruhi oleh kondisi objek yang diteliti dan kemampuan orang yang menggunakan instrumen untuk mengumpulkan data. Selain memenuhi persyaratan validitas dan reliabilitas, instrumen hendaknya memenuhi persyaratan kepraktisan. Artinya instrumen tersebut praktis untuk dilaksanakan, diringkas, mudah dimengerti dan hemat biaya.Berdasarkan latar belakang yang telah di paparkan di atas peneliti tertarik untuk melakukan penelitian dengan judul “Validitas dan reliabilitas instrumen kecemasan belajar matematika".

\section{METODE PENELITIAN}

Berdasarkan permasalahan yang diteliti, metode penelitian yang digunakan pada penelitian ini adalah metode survey. Penelitian survey merupakan penelitian yang diadakan untuk memperoleh fakta-fakta dari gejalagejala yang ada dan mencari keterangan-keterangan secara faktual baik tentang institusi sosial, ekonomi ataupun politik. Metode penelitian yang digunakan adalah metode survey yaitu penelitian deskriptif analisis dengan pendekatan kuantitatif. Populasi dalam penelitian ini adalah seluruh siswa MAS Raudhatun Najah Langsa yang berjumlah 138 siswa. Sampel dalam penelitian ini diambil dengan menggunakan teknik sampling jenuh dimana semua anggota populasi digunakan sebagai sampel. Teknik pengumpulan data yang digunakan pada penelitian ini berupa non tes, sedangkan instrumen penelitian yang digunakan adalah angket.

Angket adalah daftar pertanyaan yang diberikan kepada orang lain yang bersedia memberikan respons sesuai dengan permintaan pengguna. ${ }^{9}$ Angket yang akan digunakan dalam penelitian ini adalah angket tertutup atau disebut juga dengan close from questioner yaitu kuesioner dengan skala likert. Skala likert digunakan untuk mengukur sikap, pendapat dan persepsi seseorang atau sekelompok orang tentang fenomena sosial. ${ }^{10}$ Skala likert yang digunakan dalam penelitian ini dibuat dalam bentuk checklist. Berikut akan ditampilkan kisi-kisi instrumen angket kecemasan belajar matematika:

\footnotetext{
9 H. Djaali dan Pudji Muljono, Pengukuran dalam... ,hlm 66

${ }^{10}$ H. Djaali dan Pudji Muljono, Pengukuran dalam... ,hlm 134.
} 
176 | TAZKIR: Jurnal Penelitian Ilmu-ilmu Sosial dan Keislaman

Vol. 04 No. 1 Juni 2018

Tabel 1 Kisi-kisi instrumen angket kecemasan belajar matematika

\begin{tabular}{|c|c|c|c|c|}
\hline \multirow[t]{2}{*}{ Dimensi } & \multirow[t]{2}{*}{ Sub dimensi } & \multirow[t]{2}{*}{ Indikator } & \multicolumn{2}{|c|}{ Nomor Soal } \\
\hline & & & Positif & Negatif \\
\hline \multirow{21}{*}{$\begin{array}{l}\text { Faktor-faktor } \\
\text { yang } \\
\text { mempengaruhi } \\
\text { kecemasan } \\
\text { belajar } \\
\text { matematika }\end{array}$} & 1. Kepercayaan & Mental & 1 & 2 \\
\hline & diri & b. Kemampuan & 3 & 4 \\
\hline & 2. Motivasi diri & a. Dorongan & 5 & 6 \\
\hline & & b. Tujuan & & \\
\hline & & & 7 & 8 \\
\hline & $\begin{array}{l}\text { 3. Pengalaman } \\
\text { dimasa lalu }\end{array}$ & $\begin{array}{l}\text { a. Kegagalan } \\
\text { sebelumnya }\end{array}$ & 9 & 10 \\
\hline & & b. Putus asa & 11 & 12 \\
\hline & 4. Self Esteem & $\begin{array}{l}\text { a. Pandangan siswa tentang } \\
\text { dirinya sendiri }\end{array}$ & 13 & 14 \\
\hline & & b. Evaluasi diri & 15 & 16 \\
\hline & 5. Emosi & $\begin{array}{l}\text { a. Mampu menerima sudut } \\
\text { pandang orang lain }\end{array}$ & 17 & 18 \\
\hline & & $\begin{array}{l}\text { b. Memiliki sikap empati terhadap } \\
\text { perasaan orang lain }\end{array}$ & 19 & 20 \\
\hline & 6. Sekolah & a. Kurikulum & 21 & 22 \\
\hline & & b. Guru & 23 & 24 \\
\hline & 7. Keluarga & a. Harapan orang tua & 25 & 26 \\
\hline & & b. Cara orang tua mendidik & 27 & 28 \\
\hline & 8. Kepribadian & a. Cara guru mengajar & 29 & 30 \\
\hline & $\begin{array}{l}\text { Guru } \\
\text { Matematika }\end{array}$ & $\begin{array}{l}\text { b. Sikap guru dalam mengajar } \\
\text { siswa }\end{array}$ & 31 & 32 \\
\hline & 9. Bakat & $\begin{array}{l}\text { a. Senang dan giat belajar } \\
\text { matematika }\end{array}$ & 33 & 34 \\
\hline & & $\begin{array}{l}\text { b. Mampu mengerjakan } \\
\text { yang diberikan }\end{array}$ & 35 & 36 \\
\hline & 10. Kecerdasan & Kemampuan belajar & 37 & 38 \\
\hline & & $\begin{array}{ll} & \text { matematika } \\
\text { b. } & \text { Kecakapan menyesuaikan diri }\end{array}$ & 39 & 40 \\
\hline
\end{tabular}

\section{HASIL DAN PEMBAHASAN}

\section{Hasil Penelitian}

Sebelum melaksanakan penelitian di MAS Raudhatun Najah Langsa, terlebih dahulu peneliti meminta izin kepada kepala sekolah di MAS Raudhatun Najah Langsa untuk melakukan penelitian pada hari Sabtu tanggal 22 April 2017. Pada penelitian ini yang ingin dianalisis yaitu validitas dan reliabilitas instrumen kecemasan belajar matematika dengan menggunakan analisis faktor konfimatori, yaitu suatu teknik analisis faktor yang berdasarkan teori atau konsep yang sudah diketahui sebelumnya. Proses analisis faktor ini menggunakan bantuan software SPSS 17.

\section{Analisis Data}




\section{a. Hasil Uji Validitas Instrumen}

Uji validitas akan menguji masing-masing item pernyataan yang digunakan dalam penelitian ini, dimana dalam penelitian ini memuat 40 item pernyataan yang harus dijawab oleh 100 responden. Adapun kriteria yang digunakan dalam menentukan valid tidaknya pernyataan yang digunakan dalam penelitian ini adalah sebagai berikut: $r_{\text {tabel }}$ dicari pada signifikan $5 \%$, derajat kebebasan $(\mathrm{df})=\mathrm{n}-2=100-2=98$. Didapat $\mathrm{r}_{\mathrm{tabel}}=0,197$. Jika $r_{\text {hitung }} \geq r_{\text {tabel }}$ dan nilai $\mathrm{r}$ positif, maka butir pernyataan dikatakan valid. Dan apabila nilai $r_{\text {hitung }} \geq r_{\text {tabel }}$ maka butir pertanyaan dinyatakan tidak valid dan harus dikeluarkan. Berdasarkan hasil uji validitas yang dilakukan dengan bantuan SPSS versi 17, dari 40 item pertanyaan terdapat 31 item pertanyaan yang valid dan 9 item pertanyaan dinyatakan tidak valid. Selanjutnya item pertanyaan yang tidak valid tersebut harus dikeluarkan.

\section{b. Hasil Uji Reliabilitas Instrumen}

Dari hasil uji validitas, selanjutnya item soal yang valid dilakukan pengujian reliabilitas. Metode pengujian reliabilitas yang digunakan adalah Cronbach's Alfa dengan bantuan SPSS versi 17. Untuk jumlah data (n) = 100 dan taraf signifikan 0,05 diperoleh $\mathrm{r}$ kritis product moment sebesar 0,196 dan hasil uji reliabilitas pada penelitian ini dapat dilihat pada tabel 3.1 berikut:

Tabel 2 Hasil Uji Reabilitas

angket dengan SPSS

\begin{tabular}{|l|l|}
\hline Cronbach's Alpha & N of Items \\
\hline .741 & 31 \\
\hline
\end{tabular}

Berdasarkan hasil uji reabilitas pada tabel 3.1 didapat nilai Cronbach's Alfa sebesar 0,741. Karena nilai alpha angket tersebut lebih besar dari r kritis Product Moment, maka instrumen dikatakan reliabel

\section{c. Analisis Faktor}

1) Identifikasi Kecukupan Data (Validitas) dan Korelasi antar Variabel (Reliabilitas)

Kecukupan data dapat diidentifikasi melalui nilai Kaiser-Mayer-Olkin MSA (KMO-MSA). Nilai tersebut diperoleh dengan menggunakan bantuan 
software SPPS 17. Berdasarkan aturan yang telah ditetapkan pada teori analisis faktor bahwa sekelompok data dikatakan memenuhi asumsi kecukupan data atau valid jika data tersebut menghasilkan nilai Kaiser-MayerOlkin MSA (KMO-MSA) lebih besar daripada 0,5. Sedangkan untuk mengidentifikasi korelasi atau hubungan antar variabel (reliabel) juga digunakan bantuan software SPSS 17 yaitu dengan melihat nilai dari Bartlett's Test of Sphericity. Berdasarkan landasan teori bahwa untuk uji korelasi antar variabel memiliki dua hipotesis yaitu sebagai berikut:

$\mathrm{H}_{\mathrm{o}}$ : Tidak ada korelasi antarvariabel bebas $\left(\mathrm{X}_{1}, \mathrm{X}_{2}, \mathrm{X}_{3}, \ldots, \mathrm{X}_{31}\right)$

$\mathrm{H}_{1}$ :Ada korelasi antarvariabel bebas $\left(\mathrm{X}_{1}, \mathrm{X}_{2}, \mathrm{X}_{3}, \ldots, \mathrm{X}_{31}\right)$

Kriteria pengujian dengan melihat nilai signifikansi yaitu terima $\mathrm{H}_{0}$ jika Sig.> 0,05 atau tolak $\mathrm{H}_{0}$ jika Sig. $<0,05$.

Hasil dari Kaiser-Mayer-Olkin MSA (KMO-MSA) dan Bartlett's Test setelah dilakukannya pengolahan data dengan menggunakan SPSS 17 dapat dilihat pada Tabel 3.2 di bawah ini:

Tabel 3 KMO and Bartlett's Test

\begin{tabular}{|lcc|c|}
\hline Kaiser-Meyer-Olkin Measure of Sampling Adequacy. & .670 \\
Bartlett's & Test & of Approx. Chi-Square & 1670.176 \\
Sphericity & Df & 465 \\
& Sig. & .000 \\
\hline
\end{tabular}

Berdasarkan Tabel 4.4 diketahui asumsi kecukupan data terpenuhi dengan nilai Kaiser-Mayer-Olkin MSA (KMO-MSA) sebesar 0,670. Nilai KMOMSA yang didapatkan lebih dari 0,5. Jadi data tersebut memenuhi nilai untuk kecukupan data (valid). Sedangkan nilai dari Bartlett's Test of Sphericity dengan Chi-Square 1670,176 dan nilai Sig. =0,000. Karena Sig. $<0,05$ maka $\mathrm{H}_{0}$ ditolak dan $\mathrm{H}_{1}$ diterima. Artinya benar-benar ada korelasi antarvariabel bebas. Sehingga dapat disimpulkan uji kecukupan data (validitas) dan asumsi korelasi (reliabel) telah terpenuhi, dengan demikian kedua asumsi untuk analisis faktor terpenuhi dan dapat dianalisis lebih lanjut.

\section{2) Menentukan Metode Analisis Faktor}

Setelah melakukan analisis variabel, maka langkah selanjutnya adalah menentukan metode yang digunakan dalam analisis faktor. Penelitian ini menggunakan metode Principal Components Analysis (PCA). Hasil pengolahan data dengan menggunakan Principal Components Analysis (PCA) dapat dilihat pada Communalities (peranan faktor). Dalam Communalities faktor yang 
terbentuk merupakan satu kesatuan, yaitu peranan dari masing-masing subvariabel dapat dijelaskan oleh faktor yang telah terbentuk (Component). Adapun hasil Communalitie dapat dilihat pada tabel 3.3 berikut ini:

\begin{tabular}{|c|c|c|}
\hline & Initial & Extraction \\
\hline $\mathrm{X} 2$ & 1.000 & .654 \\
\hline X3 & 1.000 & .663 \\
\hline X4 & 1.000 & .668 \\
\hline X5 & 1.000 & .804 \\
\hline X6 & 1.000 & .667 \\
\hline X7 & 1.000 & .749 \\
\hline X9 & 1.000 & .571 \\
\hline X10 & 1.000 & .742 \\
\hline $\mathrm{X} 12$ & 1.000 & .628 \\
\hline X15 & 1.000 & .612 \\
\hline X16 & 1.000 & .623 \\
\hline X18 & 1.000 & .654 \\
\hline X20 & 1.000 & .616 \\
\hline X21 & 1.000 & .659 \\
\hline X22 & 1.000 & .634 \\
\hline X23 & 1.000 & .763 \\
\hline X24 & 1.000 & .758 \\
\hline X25 & 1.000 & .703 \\
\hline X26 & 1.000 & .709 \\
\hline X27 & 1.000 & .672 \\
\hline X28 & 1.000 & .700 \\
\hline X29 & 1.000 & .785 \\
\hline X30 & 1.000 & .708 \\
\hline X31 & 1.000 & .618 \\
\hline X32 & 1.000 & .686 \\
\hline X33 & 1.000 & .664 \\
\hline X34 & 1.000 & .619 \\
\hline X35 & 1.000 & .781 \\
\hline X36 & 1.000 & .750 \\
\hline X37 & 1.000 & .683 \\
\hline X40 & 1.000 & .734 \\
\hline
\end{tabular}

Extraction Method: Principal Component Analysis.

Tabel 3 menunjukkan beberapa varians yang dapat dijelaskan oleh faktor yang telah diekstrak (faktor yang terbentuk). Setiap variabel berkorelasi dengan faktor-faktor yang terbentuk. Dengan kata lain 
communality tersebut menunjukkan bahwa jumlah varian yang disumbangkan oleh suatu variabel lainnya dalam analisis dengan menggunakan metode Principal Components Analysis (PCA). Untuk setiap variabel masing-masing memiliki nilai communality sebesar 1 (satu).

Berdasarkan tabel communality diketahui bahwa variabel $\mathrm{X}_{5}$ merupakan peranan variabel penyusun faktor terbesar yang dapat dijelaskan oleh faktor yang telah terbentuk (component) dengan nilai 0,804 atau sekitar $80,4 \%$. Sedangkan variabel $X_{9}$ merupakan peranan variabel penyusun faktor terkecil yang dapat dijelaskan oleh faktor yang telah terbentuk (component) dengan nilai 0,571 atau sekitar $57,1 \%$.

\section{3) Penentuan Banyak Faktor dengan Eigenvalue dan Scree Plot}

Untuk menentukan banyaknya faktor yang terbentuk dari variabelvariabel yang tersisa dapat ditentukan dengan nilai eigenvalue. Berdasarkan landasan teori bahwa nilai eigenvalue yang lebih dari atau sama dengan 1 (satu) yang akan dimasukkan sebagai faktor bersama (component). Dengan menggunakan bantuan software SPSS versi 17, diperoleh nilai eigenvalue yang terdapat pada tabel 3.4 berikut ini:

Tabel 4 Total Variance Explained

\begin{tabular}{|c|c|c|c|c|c|c|c|c|c|}
\hline \multirow[b]{2}{*}{$\begin{array}{l}\text { Compone } \\
\text { nt }\end{array}$} & \multicolumn{3}{|c|}{ Initial Eigenvalues } & \multicolumn{3}{|c|}{$\begin{array}{c}\text { Extraction Sums of Squared } \\
\text { Loadings }\end{array}$} & \multicolumn{3}{|c|}{$\begin{array}{c}\text { Rotation Sums of Squared } \\
\text { Loadings }\end{array}$} \\
\hline & Total & $\begin{array}{c}\% \text { of } \\
\text { Variance }\end{array}$ & $\begin{array}{c}\text { Cumulati } \\
\text { ve } \%\end{array}$ & Total & $\begin{array}{c}\% \text { of } \\
\text { Variance }\end{array}$ & $\begin{array}{c}\text { Cumulati } \\
\text { ve } \%\end{array}$ & Total & $\begin{array}{c}\% \text { of } \\
\text { Variance }\end{array}$ & $\begin{array}{c}\text { Cumulati } \\
\text { ve } \%\end{array}$ \\
\hline 1 & 5.985 & 19.307 & 19.307 & 5.985 & 19.307 & 19.307 & 3.870 & 12.484 & 12.484 \\
\hline 2 & 3.076 & 9.924 & 29.231 & 3.076 & 9.924 & 29.231 & 2.697 & 8.701 & 21.186 \\
\hline 3 & 2.201 & 7.099 & 36.330 & 2.201 & 7.099 & 36.330 & 2.242 & 7.233 & 28.419 \\
\hline 4 & 1.971 & 6.359 & 42.689 & 1.971 & 6.359 & 42.689 & 2.213 & 7.139 & 35.558 \\
\hline 5 & 1.676 & 5.405 & 48.094 & 1.676 & 5.405 & 48.094 & 2.153 & 6.945 & 42.503 \\
\hline 6 & 1.447 & 4.667 & 52.761 & 1.447 & 4.667 & 52.761 & 1.781 & 5.745 & 48.248 \\
\hline 7 & 1.430 & 4.612 & 57.373 & 1.430 & 4.612 & 57.373 & 1.689 & 5.448 & 53.697 \\
\hline 8 & 1.336 & 4.310 & 61.683 & 1.336 & 4.310 & 61.683 & 1.564 & 5.045 & 58.742 \\
\hline 9 & 1.087 & 3.506 & 65.189 & 1.087 & 3.506 & 65.189 & 1.537 & 4.960 & 63.701 \\
\hline 10 & 1.067 & 3.443 & 68.632 & 1.067 & 3.443 & 68.632 & 1.528 & 4.931 & 68.632 \\
\hline 11 & .964 & 3.109 & 71.741 & & & & & & \\
\hline 12 & .858 & 2.769 & 74.510 & & & & & & \\
\hline 13 & .809 & 2.609 & 77.119 & & & & & & \\
\hline 14 & .724 & 2.335 & 79.454 & & & & & & \\
\hline 15 & .687 & 2.215 & 81.669 & & & & & & \\
\hline 16 & .638 & 2.059 & 83.728 & & & & & & \\
\hline 17 & .570 & 1.840 & 85.567 & & & & & & \\
\hline 18 & .533 & 1.719 & 87.286 & & & & & & \\
\hline 19 & .493 & 1.589 & 88.875 & & & & & & \\
\hline 20 & .473 & 1.526 & 90.401 & & & & & & \\
\hline
\end{tabular}


\begin{tabular}{|l|r|r|r|}
\begin{tabular}{l|r|r|}
21 \\
22
\end{tabular} & .420 & 1.353 & 91.754 \\
23 & .408 & 1.316 & 93.070 \\
.366 & 1.182 & 94.252 \\
24 & .329 & 1.060 & 95.313 \\
25 & .294 & .949 & 96.262 \\
26 & .268 & .865 & 97.127 \\
27 & .228 & .735 & 97.862 \\
28 & .196 & .631 & 98.492 \\
29 & .181 & .583 & 99.075 \\
30 & .156 & .504 & 99.579 \\
31 & .130 & .421 & 100.000
\end{tabular}

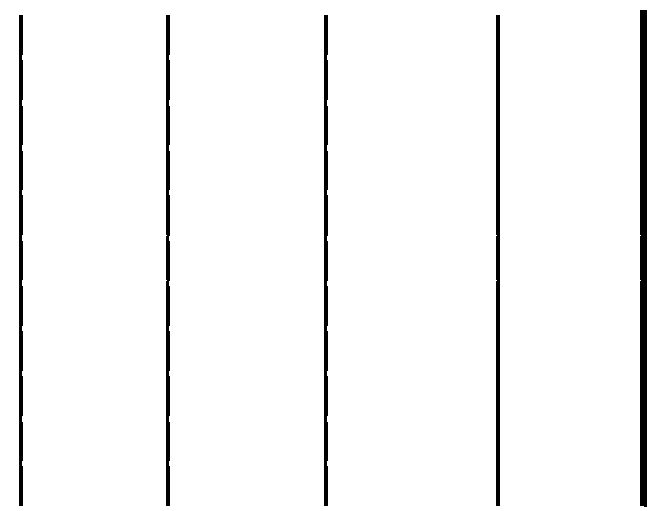

Berdasarkan tabel 4 dapat dilihat ada 10 komponen (faktor bersama) yang mempunyai nilai eigenvalue yang lebih dari 1 (satu). 10 komponen tersebut menyumbang sebanyak 68,632\% varians dari seluruh varian asli. Sedangkan 21 komponen lainnya hanya menyumbang sebesar 31,368\%. Akan tetapi dari 10 faktor tersebut, hanya 5 faktor saja yang memberi sumbangan varians yang melebihi $5 \%$ yaitu faktor $1(19,307 \%)$ dengan nilai eigenvalue 5,985, faktor 2 $(9,924 \%)$ dengan nilai eigenvalue 3,076, faktor $3(7,099 \%)$ dengan nilai eigenvalue 2.201, faktor $4(6,359 \%)$ dengan nilai eigenvalue 1,971 dan faktor 5 (5,405\%) dengan nilai eigenvalue 1,676. Dari hasil tersebut maka dapat disimpulkan ada 5 faktor bersama yang dapat terbentuk dari analisis ini.

Penentuan jumlah banyaknya faktor yang terbentuk juga dapat dilihat berdasarkan graf scree plot. Scree Plot merupakan suatu plot dari eigenvalue sebagai fungsi banyaknya faktor, dalam upaya untuk ekstraksi. Bentuk scree plot dipergunakan untuk menentukan banyaknya faktor. Berikut akan ditampilkan graf screen plot:

Scree Plot

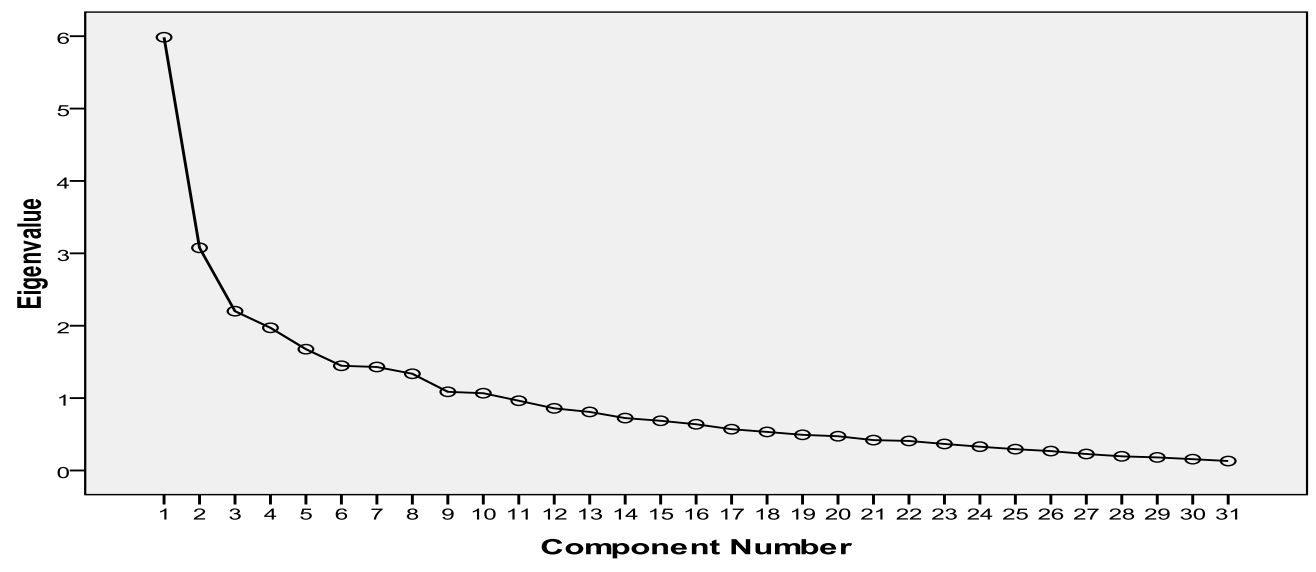


Berdasarkan graf screen plot di atas, ada lima faktor yang terbentuk. Hal ini dapat terlihat dari 31 faktor, terdapat 5 faktor yang membentuk graf yang tegak menjadi mendatar. Berdasarkan nilai eigenvalue dan scree plot maka dapat disimpulkan ada 5 faktor bersama yang dapat terbentuk dari analisis ini.

\section{4) Melakukan Rotasi Faktor}

Sebelum menginterpretasikan hasil faktor langkah yang harus dilakukan adalah melakukan rotasi faktor terlebih dahulu, yaitu untuk mengetahui korelasi antara faktor dengan variabel, dan hanya korelasi yang diwakili factor loading (faktor yang berkorelasi) yang mempunyai nilai di atas 0,30 yang dianggap cukup kuat berkorelasi. Hasil korelasi faktor dengan variabel sebelum di rotasi faktor dapat dilihat pada tabel 3.5 berikut ini:

Tabel 5 Component Matrix ${ }^{a}$

\begin{tabular}{|l|l|l|l|l|l|}
\hline & \multicolumn{5}{|c|}{ Component } \\
\hline & 1 & 2 & 3 & 4 & 5 \\
\hline X32 & .692 & & & & \\
X37 & .683 & & & & \\
X24 & .663 & & & & \\
X6 & .639 & & & & \\
X15 & .636 & & & & \\
X35 & .634 & & & & \\
X33 & .627 & & & & \\
X12 & .609 & & & & \\
X9 & .588 & & & & \\
X3 & .579 & & & & \\
X7 & .557 & -.369 & & & \\
X5 & .500 & & & & \\
X31 & .442 & -.343 & & & \\
X22 & .398 & & & & \\
X30 & .445 & .693 & & & \\
X40 & .355 & .555 & & & \\
X18 & .350 & .551 & & \\
X36 & & .519 & & & \\
X10 & & -.445 & & & \\
\end{tabular}




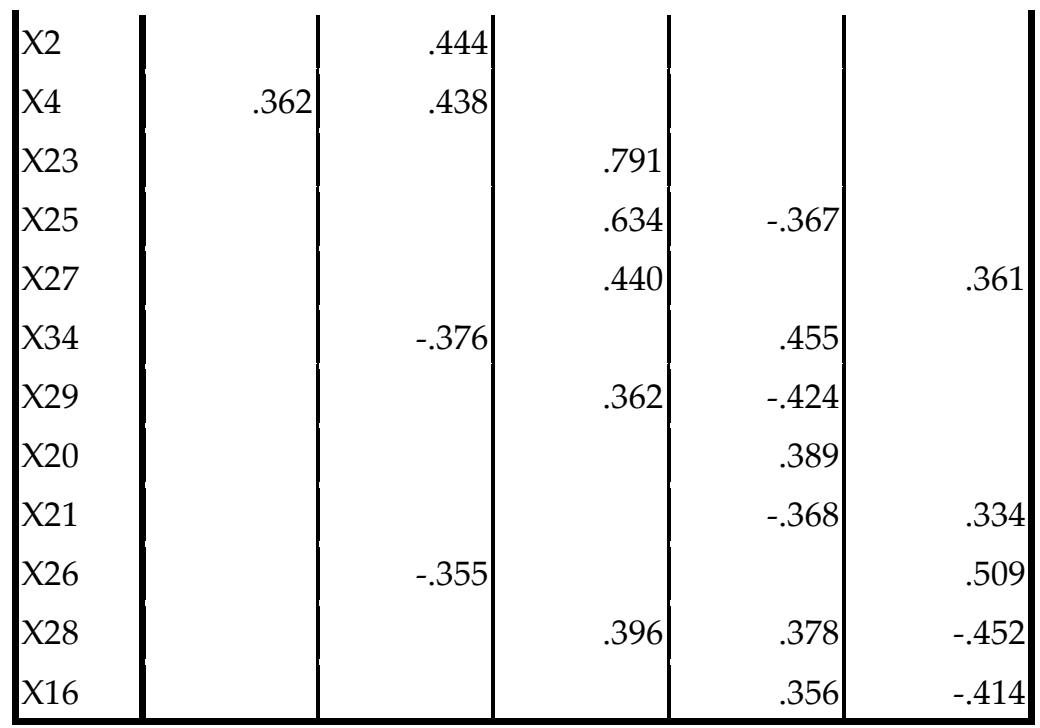

Tabel

Extraction Method: Principal Component Analysis.

memperlihatkan korelasi antar item variabel dengan faktornya. Dari tabel component matrix diperoleh bahwa variabel berkorelasi dengan banyak faktor, seperti variabel $X_{7}, X_{31}, X_{30}, X_{40}$ dan $X_{4}$ yang berkorelasi dengan faktor 1 dan 2 . Variabel $X_{6}$ berkorelasi dengan faktor 1 dan 4 . Variabel $X_{18}$ yang berkorelasi dengan faktor 1,2 dan 3. Variabel $X_{10}$ dan $X_{34}$ yang berkorelasi dengan faktor 2 dan 4 . Variabel $X_{25}$ dan $X_{29}$ yang berkorelasi dengan faktor 3 dan 4 . Variabel $X_{27}$ yang berkorelasi dengan faktor 3 dan 5. Variabel $X_{21}$ dan $X_{16}$ yang berkorelasi dengan faktor 4 dan 5. Dan Variabel $X_{28}$ yang berkorelasi dengan faktor 3, 4 dan 5. Karena banyak variabel-variabel yang berkorelasi lebih dari 1 faktor, maka perlu dilakukannya rotasi faktor. Hasil dari rotasi faktor dapat dilihat pada tabel 3.6 berikut ini:

Tabel 6 Rotated Component Matrix ${ }^{a}$

\begin{tabular}{lccccc}
\hline \multicolumn{5}{c}{ Component } \\
& 1 & & 2 & 3 & 5 \\
\hline X37 & .774 & & & \\
X15 & .700 & & & \\
X35 & .677 & & & \\
X7 & .668 & & & \\
X33 & .626 & & & \\
X3 & .583 & & & & \\
X12 & .570 & & & & \\
X9 & .560 & & & & \\
X32 & .559 & .369 & & \\
X6 & .546 & & & & \\
X31 & .528 & & & &
\end{tabular}


184 | TAZKIR: Jurnal Penelitian Ilmu-ilmu Sosial dan Keislaman

Vol. 04 No. 1 Juni 2018

\begin{tabular}{|c|c|c|c|c|}
\hline X5 & & .489 & & \\
\hline X24 & & .473 & .467 & \\
\hline X30 & & & .792 & \\
\hline $\mathrm{X} 18$ & & & .714 & \\
\hline X40 & & & .674 & \\
\hline X36 & & & .592 & \\
\hline $\mathrm{X} 4$ & & & .485 & -.368 \\
\hline $\mathrm{X} 2$ & & & .463 & \\
\hline $\mathrm{X} 22$ & & & .460 & \\
\hline $\mathrm{X} 23$ & & & .792 & \\
\hline X25 & & & .715 & \\
\hline X29 & .342 & & .565 & \\
\hline $\mathrm{X} 26$ & & & & .578 \\
\hline X20 & & & & .548 \\
\hline $\mathrm{X} 27$ & & & .338 & .428 \\
\hline X10 & .395 & & & .403 \\
\hline X28 & & & & .652 \\
\hline X16 & & & & .547 \\
\hline X34 & & & & .366 .514 \\
\hline X21 & & & & -.468 \\
\hline
\end{tabular}

Extraction Method: Principal Component Analysis.

Rotation Method: Varimax with Kaiser Normalization.

a. Rotation converged in 8 iterations.

Pada tabel 6 menunjukkan korelasi antar variabel dengan faktornya setelah dilakukan rotasi. Dari tabel diperoleh faktor 1 berkorelasi kuat dengan variabel $X_{37}, X_{15}, X_{35}, X_{7}, X_{33}, X_{3}, X_{9}, X_{31}$ dan $X_{5}$. Faktor 2 berkorelasi kuat dengan variabel $X_{30}, X_{18}, X_{40}, X_{36}, X_{2}$ dan $X_{22}$. Faktor 3 berkorelasi kuat dengan variabel $X_{23}$ dan $X_{25}$. Faktor 4 berkorelasi kuat dengan variabel $X_{26}$ dan $X_{20}$. Dan faktor 5 berkorelasi kuat dengan variabel $X_{28}$ dan $X_{16}$. Sedangkan variabel $X_{12}, X_{32}, X_{6}, X_{24}, X_{4}, X_{29}, X_{27}, X_{10}$ dan $X_{34}$ dikeluarkan dari analisis karena dapat tergolong kedalam dua faktor. Selain itu variabel $X_{21}$ dikeluarkan juga dari analisis karena mempunyai nilai <0,30. Dari hasil tersebut dapat disimpulkan bahwa setiap variabel hanya berkorelasi pada satu faktor saja sehingga mudah untuk diinterpretasikan.

\section{5) Membuat Interpretasi Hasil Faktor}

Setelah dilakukan rotasi terhadap faktor-faktor, langkah terakhir dalam analisis faktor yaitu menginterpretasikan item-item pernyataan ke dalam faktor bersama yang telah terbentuk. Berdasarkan hasil rotasi faktor maka terbentuk 5 faktor bersama (faktor utama) yang dijabarkan sebagai berikut: 
Tabel 7 Faktor-faktor Yang Mempengaruhi Kecemasan Siswa dalam

Pembelajaran Matematika

\begin{tabular}{|c|c|c|c|c|c|}
\hline Faktor & Item & $\begin{array}{l}\text { Muatan } \\
\text { Faktor }\end{array}$ & Deskripsi item & $\begin{array}{l}\text { Nilai } \\
\mathbf{r}\end{array}$ & $\begin{array}{l}\text { Nilai } \\
\alpha\end{array}$ \\
\hline Faktor 1 & Item 37 & 0,774 & $\begin{array}{l}\text { Saya akan memanfaatkan waktu untuk } \\
\text { belajar matematika secara mandiri di } \\
\text { perpustakaan }\end{array}$ & 0,706 & 0,734 \\
\hline \multirow[t]{8}{*}{ Bakat } & Item 15 & 0,7 & $\begin{array}{l}\text { Saya mampu dalam matematika, sehingga } \\
\text { saya ingin mengembangkan kemampuan } \\
\text { matematika saya lebih baik lagi }\end{array}$ & 0,499 & \\
\hline & Item 35 & 0,677 & $\begin{array}{l}\text { Saya sering berlatih mengerjakan soal } \\
\text { matematika yang sulit untuk melatih } \\
\text { kemampuan matematika saya }\end{array}$ & 0,647 & \\
\hline & Item 7 & 0,668 & $\begin{array}{l}\text { Saya rajin mempelajari matematika untuk } \\
\text { mendapatkan nilai yang tinggi }\end{array}$ & 0,476 & \\
\hline & Item 33 & 0,626 & $\begin{array}{l}\text { Saya selalu semangat ketika belajar } \\
\text { matematika }\end{array}$ & 0,736 & \\
\hline & Item 3 & 0,583 & $\begin{array}{l}\text { Saya dapat menjelaskan soal matematika } \\
\text { yang tidak dipahami teman-teman }\end{array}$ & 0,571 & \\
\hline & Item 9 & 0,56 & $\begin{array}{l}\text { Saya terus giat belajar matematika walaupun } \\
\text { telah mendapatkan nilai yang buruk }\end{array}$ & 0,576 & \\
\hline & Item 31 & 0,528 & $\begin{array}{l}\text { Guru matematika yang tegas dan disiplin } \\
\text { akan membuat saya lebih fokus }\end{array}$ & 0,384 & \\
\hline & Item 5 & 0,489 & $\begin{array}{l}\text { Saya mengulang kembali materi pelajaran } \\
\text { matematika yang disampaikan guru agar } \\
\text { lebih paham }\end{array}$ & 0,482 & \\
\hline Faktor 2 & Item 30 & 0,792 & $\begin{array}{l}\text { Guru yang humoris membuat saya lebih } \\
\text { senang belajar matematika }\end{array}$ & 0,775 & 0,762 \\
\hline \multirow[t]{3}{*}{$\begin{array}{l}\text { Proses } \\
\text { Belajar }\end{array}$} & Item 18 & 0,714 & $\begin{array}{l}\text { Saya akan mempertahankan pendapat saat } \\
\text { berdiskusi }\end{array}$ & 0,762 & \\
\hline & Item 40 & 0,674 & $\begin{array}{l}\text { Saya lebih fokus belajar matematika jika } \\
\text { tidak ada teman yang mengganggu }\end{array}$ & 0,628 & \\
\hline & Item 36 & 0,592 & $\begin{array}{l}\text { Saya bisa mengerjakan soal matematika jika } \\
\text { soal yang diberikan sama persis dengan } \\
\text { contoh yang diajarkan guru }\end{array}$ & 0,753 & \\
\hline
\end{tabular}


186 | TAZKIR: Jurnal Penelitian Ilmu-ilmu Sosial dan Keislaman

Vol. 04 No. 1 Juni 2018

\begin{tabular}{|c|c|c|c|c|c|}
\hline & Item 2 & 0,463 & $\begin{array}{l}\text { Saya lebih suka menyendiri daripada } \\
\text { berbaur dengan teman bila ada masalah }\end{array}$ & 0,521 & \\
\hline & Item 22 & 0,46 & $\begin{array}{l}\text { Saya jenuh belajar matematika jika diberikan } \\
\text { tugas yang banyak }\end{array}$ & 0,536 & \\
\hline Faktor 3 & Item 23 & 0,792 & $\begin{array}{l}\text { Kemampuan guru dalam mengajar akan } \\
\text { membuat saya termotivasi untuk belajar }\end{array}$ & 0,832 & 0,853 \\
\hline Motivasi & Item 25 & 0,715 & $\begin{array}{l}\text { Orang tua saya menginginkan saya } \\
\text { berprestasi di sekolah }\end{array}$ & 0,829 & \\
\hline Faktor 4 & Item 26 & 0,578 & $\begin{array}{l}\text { Orang tua saya tidak pernah memeriksa nilai } \\
\text { matematika saya }\end{array}$ & 0,828 & 0,845 \\
\hline emosi & Item 20 & 0,548 & $\begin{array}{l}\text { Saya tidak tertarik berbicara dengan teman } \\
\text { yang lambat memahami penjelasan saya }\end{array}$ & 0,808 & \\
\hline Faktor 5 & Item 28 & 0,652 & $\begin{array}{l}\text { Saya rajin belajar karena orang tua saya } \\
\text { selalu melengkapi fasilitas belajar saya }\end{array}$ & 0,946 & 0,91 \\
\hline Keluarga & Item 16 & 0,547 & $\begin{array}{l}\text { Saya merasa puas dengan nilai matematika } \\
\text { saya karena hanya sejauh itu kemampuan } \\
\text { saya }\end{array}$ & 0,926 & \\
\hline
\end{tabular}

Berdasarkan tabel di atas dapat disimpulkan bahwa terbentuk 5 faktor yang mempengaruhi kecemasan siswa dalam pembelajaran matematika di MAS Raudhatun Najah Langsa, yaitu faktor 1 bakat, faktor 2 proses belajar, faktor 3 motivasi, faktor 4 emosi dan faktor 5 keluarga. Faktor ini terbentuk dari 21 item pertanyaan yang telah dinyatakan valid dan reliabel sebagai instrumen untuk mengukur kecemasan belajar matematika.

\section{PEMBAHASAN}

Berdasarkan hasil penelitian yang dilakukan di MAS Raudhatun Najah Langsa Tahun Ajaran 2016-2017 semester 2 yang berpopulasi sebanyak 138 siswa. Peneliti melakukan analisa data dengan menggunakan analisis faktor, yaitu analisis konfimatori dengan menggunakan bantuan software SPSS versi 17. Data tersebut diperoleh melalui penyebaran angket kepada sampel penelitian, dalam hal ini adalah siswa MAS Raudhatun Najah Langsa semester 2 yang berjumlah 138 orang.

Hasil penelitian diperoleh nilai KMO-MSA sebesar 0,670, sedangkan Bartlett's Testof Sphericity dengan Chi-Square $1670.176(\mathrm{df}=465)$ dan nilai sig. $=$ 0,000. Nilai sig. yang kurang 0,05 menyatakan bahwa hipotesis tentang variabel 
tidak saling berkorelasi ditolak, berarti data telah valid dan reliabel dan data dapat dianalisis lebih lanjut.

Langkah berikutnya yaitu menentukan metode yang digunakan dalam analisis faktor. Adapun metode yang digunakan yaitu Principal Component Analysis (PCA). Selanjutnya yaitu menentukan banyaknya faktor yang terbentuk dari 31 variabel yang ada, dengan melihat nilai persentase varians dari nilai eigenvalue yang lebih dari 5\% maka diperoleh 5 faktor yang terbentuk yaitu faktor $1(19.307 \%)$, faktor 2 (9.924\%), faktor $3(7.099 \%)$, faktor $4(6.359 \%)$ dan faktor $5(5.405 \%)$.

Setelah diketahui faktor yang telah terbentuk, selanjutnya menentukan masing-masing variabel pada setiap faktor dengan melakukan rotasi faktor (sebelum rotasi). Dari hasil tersebut terlihat bahwa variabel berkorelasi dengan banyak faktor, seperti variabel $X_{7}, X_{31}, X_{30}, X_{40}$ dan $X_{4}$ yang berkorelasi dengan faktor 1 dan 2 . Variabel $X_{6}$ berkorelasi dengan faktor 1 dan 4 . Variabel $X_{18}$ yang berkorelasi dengan faktor 1, 2 dan 3. Variabel $X_{10}$ dan $X_{34}$ yang berkorelasi dengan faktor 2 dan 4 . Variabel $X_{25}$ dan $X_{29}$ yang berkorelasi dengan faktor 3 dan 4 . Variabel $X_{27}$ yang berkorelasi dengan faktor 3 dan 5. Variabel $X_{21}$ dan $X_{16}$ yang berkorelasi dengan faktor 4 dan 5 . Dan Variabel $X_{28}$ yang berkorelasi dengan faktor 3, 4 dan 5. Karena banyak variabel-variabel yang berkorelasi lebih dari 1 faktor, maka perlu dilakukannya rotasi faktor.

Setelah dilakukannya rotasi faktor, maka diperoleh faktor 1 berkorelasi kuat dengan variabel $X_{37}, X_{15}, X_{35}, X_{7}, X_{33}, X_{3}, X_{9}, X_{31}$ dan $X_{5}$. Faktor 2 berkorelasi kuat dengan variabel $X_{30}, X_{18}, X_{40}, X_{36}, X_{2}$ dan $X_{22}$. Faktor 3 berkorelasi kuat dengan variabel $X_{23}$ dan $X_{25}$. Faktor 4 berkorelasi kuat dengan variabel $X_{26}$ dan $X_{20}$. Dan faktor 5 berkorelasi kuat dengan variabel $X_{28}$ dan $X_{16}$. Sedangkan variabel $X_{12}, X_{32}$, $X_{6}, X_{24}, X_{4}, X_{29}, X_{27}, X_{10}$ dan $X_{34}$ dikeluarkan dari analisis karena dapat tergolong kedalam dua faktor. Selain itu variabel $X_{21}$ dikeluarkan juga dari analisis karena mempunyai nilai $<0,30$.

Langkah terakhir yang dilakukan dalam analisis faktor yaitu menginterpretasikan hasil rotasi. Berdasarkan hasil rotasi faktor yang telah dilakukan maka terbentuklah 5 (lima) faktor bersama yang berkorelasi kuat terhadap variabel-variabel tersebut. Faktor baru tersebut adalah faktor 1 bakat, faktor 2 proses belajar, faktor 3 motivasi, faktor 4 emosi siswa dan faktor 5 keluarga. Faktor ini terbentuk dari 21 item pertanyaan yang telah dinyatakan 
188 | TAZKIR: Jurnal Penelitian Ilmu-ilmu Sosial dan Keislaman

Vol. 04 No. 1 Juni 2018

valid dan reliabel sebagai instrumen untuk mengukur kecemasan belajar matematika.

\section{PEUTUP}

Berdasarkan hasil penelitian dan pembahasan pada bab IV sebelumya, maka dapat disimpulkan bahwa ada 5 faktor utama (faktor bersama) yang mempengaruhi kecemasan siswa dalam Pembelajaran Matematika di MAS Raudhatun Najah Langsa. Untuk menguji kecemasan belajar matematika tersebut dengan menggunakan instrumen angket yang berjumlah 21 item pertanyaan dimana instrumen tersebut telah dinyatakan valid dan reliabel melalui analisis faktor. 
Validitas dan Reliabilitas Instrumen .....NURMAWATI, IRMA SURYANI | 189

\section{DAFTAR PUSTAKA}

Arikunto, Suharsimi. 2005. Dasar - dasar Evaluasi Pendidikan. Jakarta:Bumi Aksara.

Ekawati, Aminah. 2015. "Pengaruh Kecemasan terhadap Hasil Belajar Matematika Siswa Kelas VII SMPN 13 Banjarmasin", Jurnal Pendidikan Matematika, Vol 1, No.3.

Masruroh, Laili dan M. Dicky Reza. 2015 "Pengaruh Kecemasan Siswa pada Matematika terhadap Hasil Belajar Matematika di SMP", Jurnal Pendidikan Matematika, Vol 3, No.2.

Muljono, Pudji dan H. Djaali. 2008. Pengukuran dalam bidang Pendidikan. Jakarta: PT Gramedia Widiasarana.

Sugiono. 2009. Metode Penelitian Pendidikan, Pendekatan Kuantitatif, Kualitatif dan $R \mathcal{E D}$. Bandung: Alfabeta.

Suherman, Erman dkk. 2003. Pembelajaran Matematika Kontemporer. Bandung: JICA. 
190 | TAZKIR: Jurnal Penelitian Ilmu-ilmu Sosial dan Keislaman

Vol. 04 No. 1 Juni 2018

\section{IMPROVING STUDENTS' VOCABULARY MASTERY THROUGH CROSSWORD PUZZLE TECHNIQUE AT SD MUHAMMADIYAH 1 PADANGSIDIMPUAN}

Tri Risky Hasibuan, Eka Sustri Harida, \& Fitri Rayani Siregar IAIN Padangsidimpuan

kikyprdg@gmail.com, esha_stainpasid@yahoo.com, \& syifaquinn@gmail.com 